\title{
Is Serum C- Reactive Protein to Albumin Ratio Be A New Biomarker for Assessing Disease Activity and Quality of Life in Rheumatoid Arthritis?
}

\author{
Serum C-Reaktif Protein/Albumin Oranı, Romatoid Artritte Hastalık Aktivitesini ve Yaşam Kalitesini \\ Değerlendirmek için Yeni Bir Belirteç Olabilir Mi?
}

Elif Balevi Batur, Funda Levendoglu

Department of Physical Medicine and Rehabilitation, Selçuk University School of Medicine, Konya, Turkey
Correspondence:

Elif BALEVİ BATUR

Department of Physical Medicine and Rehabilitation, Selçuk University School of Medicine, Konya, Turkey e-mail: elifbalevi@hotmail.com

\section{Abstract}

The C-reactive protein (CRP)/albumin ratio is a biomarker that has gained importance in recent years in demonstrating systemic inflammation. The aim of this study was to evaluate the relationship of CRP/albumin ratio with disease activity and quality of life in patients with rheumatoid arthritis (RA). Fifty RA patients were included in this cross-sectional study. The CRP/albumin ratio was calculated from the blood of the individuals included in the study. The disease activity score-28 (DAS-28) measurement scale was used to determine disease activity. The Health Assessment Questionnaire (HAQ) was used to assess functional status, and the Short-form health survey 36 (SF-36) was used to assess the quality of life. When the patients were evaluated according to the disease activity level, the CRP/albumin ratio was statistically significantly higher in patients with moderate-high disease activity compared to those in remission in post-hoc analyses $(\mathrm{p}=0.006)$. In correlation analyzes, moderate and positive correlation ( $\mathrm{p}=0.002, \mathrm{rs}=0.426 ; \mathrm{p}<0.001, \mathrm{rs}=0.536$, respectively) was observed between CRP/albumin ratio and erythrocyte sedimentation rate (ESR) and DAS 28-ESR scores. When the patients were evaluated according to the drug treatments they received, no significant difference was observed between conventional DMARD and biological DMARD users in terms of CRP/albumin ratio, SF-36, and HAQ scores ( $p>0.05$ ). Our results suggest that CAR may be used in clinics to determine inflammation and disease activity as an inexpensive and easily applicable biomarker.

Keywords: C-reactive protein, albumin, rheumatoid arthritis, disease activity

\section{Özet}

Serum C- reaktif protein /albumin oranı Romatoid Artritte sistemik inflamasyonu göstermede son y1llarda önem kazanan bir biyobelirteçtir. Bu çalıșmanın amacı Romatoid artritli (RA) hastalarda CRP/ albumin oranının hastalık aktivitesi ve hayat kalitesi ile olan ilişkisini değerlendirmektir. Bu kesitsel çalışmaya 50 RA hastası dahil edilmiştir. Çalışmaya alınan bireylerin kanlarından CRP/ albumin oranı hesaplandı. Hastalık aktivitesini tayin etmek amacıyla hastalık aktivite skoru (DAS-28) ölçüm skalası kullanıld. Fonksiyonel durum değerlendirmedi için Sağlık değerlendirme anketi (HAQ) anketi, yaşam kalitesini değerlendirmek için de Kısa-form 36 (SF-36) anketi kullanıldı. Hastalar, post-hoc analizlerde hastalık aktivite düzeyine göre değerlendirildiğinde hastalık aktivitesi orta-yüksek olanlarda CRP/albumin oranının remisyondakilere oranla istatistiksel olarak anlamlı oranda yüksek olduğu

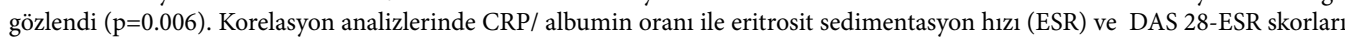
arasında 1lımlı ve pozitif yönde korelasyon $(\mathrm{p}=0.002, \mathrm{rs}=0.426 ; \mathrm{p}<0.001, \mathrm{rs}=0.536$, sırasıyla) izlendi. Hastalar aldıkları ilaç tedavilerine göre değerlendirildiğinde konvansiyonel hastalık modifiye edici anti-romatizmal ilaç (DMARD) ve biyolojik DMARD alanlar arasında CRP/albumin oranı, SF-36 ve HAQ skorları açısından anlamlı fark izlenmedi ( $>0.05$ ). Çalışmamızın sonuçları, ucuz ve kolay uygulanabilir bir biyobelirteç olarak CRP/ albumin oranının kliniklerde inflamasyon ve hastalık aktivitesini belirlemek için kullanılabileceğini düşündürmektedir.

Anahtar Kelimeler: C- reaktif protein, albumin, romatoid artrit, hastalık aktivitesi 


\section{Introduction}

Rheumatoid arthritis (RA) is an autoinflammatory chronic disease characterized by synovial inflammation that severely leads to joint deformities. Although the etiology of RA is not known precisely, it is thought to be related to genetic and environmental factors (1). The disease is characterized by synovitis, which occurs due to immunological and inflammatory responses in the joints involved in the acute stages of the disease. Ultimately cartilage-destroying enzymes, prostaglandins, leukotrienes, free radicals, and acute phase reactants lead to progressive destruction of articular cartilage and bone (2). Early diagnosis and treatment of the disease prevent irreversible joint deformations (3). It usually presents with polyarticular involvement in the hands and feet. RA is also associated with an increased risk of cardiovascular disease as an extraarticular involvement. Early diagnosis of the underlying inflammation is essential for effective treatment in rheumatoid arthritis. Furthermore, measurement of disease activity is essential to target treatment and improve outcomes (4).

Disease activity level and duration of remission play an essential role in the progression of the disease (5). Acute phase reactants are important in the diagnosis and follow-up of the disease. Laboratory parameters such as C-reactive protein (CRP), erythrocyte sedimentation rate (ESR), and disease activity score-28 (DAS-28) are used to evaluate disease activity in RA patients (6). Although ESR and CRP are the most commonly used acute phase reactants, they are non-specific, show short-term inflammation, and can be affected by many factors (7). In this sense, other biomarkers indicating inflammation are needed. Several studies suggested that $\mathrm{CRP} /$ albumin ratio $(\mathrm{CAR})$ is a new laboratory indicator and CAR concentration increased in cancer and cardiovascular disease, and is associated with the inflammation. They revealed that high CRP levels and low albumin levels were concerned with the inflammatory process and as a new predictive biomarker, CAR might be used to assess disease activity in RA patients $(8,9)$. Yang et al $(8)$ found that CAR has a correlation with DAS-28 in RA patients, and can be used as an indicator to assess the activity of RA. However, studies investigating CAR in systemic autoinflammatory diseases such as RA are scarce in the literature. Therefore, in this study we aimed to investigate the relationship between CAR and disease activity and quality of life in RA patients.

\section{Patients and Methods}

This cross-sectional study included subjects among the 50 RA patients admitted to our clinic for regular follow-up visits. The inclusion criteria were as follows; being above 18 years and diagnosed according to the American College of Rheumatology/ European League Against Rheumatism 2010 RA classification criteria (10). The exclusion criteria were an active infectious disease, pregnancy, a history of any drug modification, hematological malignancies, other chronic inflammatory diseases, liver disease, and kidney failure. Participants were fully informed about the experimental procedures and gave their informed consent. The study protocol was approved by the Selcuk University Ethics Committee (decision number: 2021/360, date: 07.07.2021) was obtained.

Patients' clinical assessments were performed by the same physician. The DAS 28 score was calculated using the number of painful joints or swollen joints, a visual analog scale (VAS), the levels of ESR according to the formula $0.56 * \sqrt{ }(\mathrm{TJC} 28)+0.28 * \sqrt{ }(\mathrm{SJC} 28)+0.70 * \ln$ $($ ESR) $+0.014 *$ VAS (General Health) (11). High disease activity related to DAS28 $>5.1$, score between 3.2 to 5.1 means moderate disease activity, and score for the low disease activity is defined in the range of 2.6 to 3.2 . A cutoff point for "remission" is defined as $<2.6$ (12).

Blood samples were analyzed from the antecubital peripheral vein of patients after after a 10-hour fast. Serum ESR was measured by Westergren's method. Serum CRP was measured using an immunoturbidimetric method with Beckman Coulter AU5800 device (IDS Co Ltd., Japan) 
with a standard range of $0-5 \mathrm{mg} / \mathrm{L}$. Albumin level was measured by the bromocresol green method (Siemens). RF was measured using the immunoturbidometric method with Beckman Coulter AU5800 device (IDS Co Ltd., Japan), and levels above $20 \mathrm{IU} / \mathrm{mL}$ were defined as positive. Anti-CCP was measured by Enzyme-linked immunosorbent assays (Euroimmunag), and levels above $5 \mathrm{U} / \mathrm{ml}$ were defined as positive.

The functional status was assessed with Health Assessment Questionnaire (HAQ). It is developed for patients with arthritis. It is a scale consisting of 20 questions. A high score indicates impaired functionality $(13,14)$.

The Quality of life (QOL) was assessed with the Short-form health survey 36 (SF-36) questionnaire. SF-36 consists of 36 items and eight domains that indicate physical functioning, physical role limitation, pain, general health, vitality, social functioning, emotional role limitation, and mental health. The score of each domain ranges from 0 (worst QOL) to 100 (the best QOL) (15). Turkish validity and reliability were proven by Kaya et al (16).

\section{Sample size}

The sample size estimation was performed using the GPower V3.1.7 (University of Kiel, Kiel, Germany). It was determined that minimum 42 participants must be recruited to detect a difference at 5\% type1 error, 0.8 effect size (effect size, $\mathrm{d}=0.8$, Cohen large effect size) and $95 \%$ power.

\section{Statistical analysis}

All statistical analyses were performed with IBM SPSS Version 22. The normality of the distribution was checked with the ShapiroWilk test. Descriptive statistics for numerical variables are presented as mean \pm standard deviation, median (min-max), and interquartile range (IQR). Statistics for categorical variables are presented as frequency (n) and percentage (\%). KruskalWallis test was used to assess the relationship between remission, low, moderate, high disease activity groups according to DAS28ESR. The differences between albumin, CAR, DAS 28-ESR, HAQ and SF-36 scores between the groups receiving conventional disease-modifying antirheumatic drug (DMARD) and biological DMARD were evaluated with the Mann Whitney-U test. Spearman's correlation coefficient (rs) was used to determine the nonparametric correlation between variables. $\mathrm{P}<0.05$ was considered the level of significance.

\section{Results}

The details regarding the demographic and clinical characteristics of patients are given in Table 1. The patients included 12 males (24\%) and 38 females (76\%), with a mean age of $46.8 \pm 11.28$ years. Of the patients, $2 \%$ were illiterate, $64 \%$ were primary and secondary school graduates, $22 \%$ were high school, and $12 \%$ were university graduates. Sixty-two percent of patients were housewives, while $26 \%$ were employed and $12 \%$ were retired. The median (min-max) ESR was $18 \mathrm{~mm} /$ hour (12-38) and median CRP was $5.18(3.38-10.72) \mathrm{mg} / \mathrm{L}$, median CAR was 1.26 (0.81-2.55), median albumin was $4.2(2.9-4.8) \mathrm{g} / \mathrm{dL}$, and median DAS28ESR was 2.99 ( 2.37-3.77). Patients doing regular aerobic exercise were $20 \%$.

Table 1. Demographic and clinical characteristics of patients $(n=50)$

\begin{tabular}{ll}
\hline Age (years)(mean \pm SD) & $\mathbf{4 6 . 8 ( \pm 1 1 . 2 8 )}$ \\
\hline Gender $(\mathbf{n})(\%)$ & $12(24 \%)$ \\
Male & $38(76 \%)$ \\
Female & \\
& \\
BMII (mean \pm SD) & $28.5( \pm 4.28)$ \\
\hline
\end{tabular}




\begin{tabular}{|c|c|}
\hline Duration of symptoms (year) (median min-max) & $8.5(1-34)$ \\
\hline $\begin{array}{l}\text { Drug }(n)(\%) \\
\text { Conventional DMARD } \\
\text { Biological DMARD }\end{array}$ & $\begin{array}{l}24(48 \%) \\
26(52 \%)\end{array}$ \\
\hline $\begin{array}{l}\text { Morning stiffness duration }(\mathrm{n})(\%) \\
30 \text { minutes } \\
30-60 \text { minutes } \\
>60 \text { minutes }\end{array}$ & $\begin{array}{l}35(70 \%) \\
5(10 \%) \\
10(20 \%)\end{array}$ \\
\hline $\begin{array}{l}\text { Regular exercise (aerobic } / 30 \mathrm{~min} / 3 \text { times a week) } \\
\text { (n)(\%) } \\
\text { Yes } \\
\text { No }\end{array}$ & $\begin{array}{l}10(20 \%) \\
40(40 \%)\end{array}$ \\
\hline $\begin{array}{l}\text { RF }(n)(\%) \\
\text { Positive } \\
\text { Negative }\end{array}$ & $\begin{array}{l}29(58 \%) \\
21(42 \%)\end{array}$ \\
\hline $\begin{array}{l}\text { Anti CCP }(n)(\%) \\
\text { Positive } \\
\text { Negative }\end{array}$ & $\begin{array}{l}36(72 \%) \\
14(28 \%)\end{array}$ \\
\hline ESR $(\mathrm{mm} / \mathrm{h})($ Median) $(25-75 \%)$ & $18(12-38)$ \\
\hline CRP (mg/dl)(Median) (25-75\%) & $5.18(3.38-10.72)$ \\
\hline CAR (Median)( (25-75\%) & $1.26(0.81-2.55)$ \\
\hline Albumin (g/dl) (Median) (25-75\%) & $4.2(2.9-4.8)$ \\
\hline DAS28-ESR(Median) (25-75\%) & $2.99(2.37-3.77)$ \\
\hline
\end{tabular}

SD Standard deviation, BMI Body mass index, DMARD disease-modifying antirheumatic drug,

RF Rheumatoid factor, Anti-CCP anti-Cyclic citrullinated peptid, ESR Eritrocyte sedimentation rate, CRP C reactive protein, CAR $C$ reactive protein to albumin ratio, DAS-28-ESR disease activity score-28- Eritrocyte sedimentation rate

In post-hoc analysis, CAR values were significantly higher in the patients with highmoderate disease activity than patients in remission $(\mathrm{p}=0.006)$. There was a significant difference in CRP between low disease and moderate-high disease activity groups $(\mathrm{p}=0.002)($ Table-2).

Table 2. Comparison of laboratory data according to DAS 28 ESR groups

\begin{tabular}{|c|c|c|c|c|}
\hline & $\begin{array}{l}\text { (Remission) } \\
(n=9)\end{array}$ & $\begin{array}{l}\text { disease } \\
\text { activity) } \\
(\mathrm{n}=22)\end{array}$ & $\begin{array}{l}\text { (Moderate-high } \\
\text { disease activity) } \\
(\mathrm{n}=19)\end{array}$ & value \\
\hline CRP (median min-max) & $3.3(1.1-19.3)$ & $6.6(1.2-25)$ & $8.9(1.6-47.5)$ & $0.002 *$ \\
\hline $\begin{array}{l}\text { Albumin (g/dl) (median } \\
\text { min-max) }\end{array}$ & $4.2(3-4.8)$ & $4.2(2.9-4.6)$ & $4.1(3.2-4.5)$ & $0.756^{\mathrm{a}}$ \\
\hline $\begin{array}{l}\text { CAR (median min- } \\
\max \text { ) }\end{array}$ & $0.758(0.23-5.03)$ & $1.546(0.3-8.5)$ & $2.21(0.4-14.8)$ & $0.006^{*}$ \\
\hline
\end{tabular}


When the patients were divided into two groups regarding receiving conventional DMARD and biological DMARD, there was no difference between the groups in terms of albumin, CAR, DAS 28-ESR, HAQ scores, and SF-36 subscales $(\mathrm{p}>0.05)$ (Table-3).

Table 3. Comparison of clinical and laboratory data according to the treatment

\begin{tabular}{|c|c|c|c|}
\hline Parameters & $\begin{array}{c}\text { Conventional } \\
\text { DMARD } \\
(\mathbf{n}=\mathbf{2 4})) \\
\end{array}$ & $\begin{array}{c}\text { Biological } \\
\text { DMARD }(n=26)\end{array}$ & p value \\
\hline HAQ score (median min-max) & $0.35(0-1.9)$ & $0.22(0-3)$ & $0.921^{\mathrm{a}}$ \\
\hline $\begin{array}{l}\text { SF -36 subscale } \\
\text { Physical Function (median min-max) } \\
\text { Physical Role Limitation (median min-max) } \\
\text { Emotional Role Limitation (median min-max) } \\
\text { Energy (mean } \pm \text { SD) } \\
\text { Emotional Well-being (mean } \pm \mathrm{SD}) \\
\text { Social Functions (median min-max) } \\
\text { Pain (median min-max) } \\
\text { General Health (median min-max) }\end{array}$ & $\begin{array}{l}65(0-100) \\
50(0-100) \\
100(0-100) \\
43.54( \pm 24.06) \\
62.83( \pm 21.4) \\
69(0-100) \\
46.5(0-100) \\
47.91( \pm 20.3)\end{array}$ & $\begin{array}{l}80(5-100) \\
100(0-100) \\
100(0-100) \\
47.50( \pm 23.4) \\
63.53( \pm 22.1) \\
81.5(13-100) \\
63(0-100) \\
50.38( \pm 22.8)\end{array}$ & $\begin{array}{l}0.270^{\mathrm{a}} \\
0.208^{\mathrm{a}} \\
0.588^{\mathrm{a}} \\
0.558^{\mathrm{b}} \\
0.910^{\mathrm{b}} \\
0.201^{\mathrm{a}} \\
0.502^{\mathrm{a}} \\
0.689^{\mathrm{b}}\end{array}$ \\
\hline DAS 28-ESR (mean \pm SD) & $2.93( \pm 0.85)$ & $3.30( \pm 1.1)$ & $0.211^{b}$ \\
\hline Albumin (median min-max) & $4.2(3-4.8)$ & $4.19(2.9-4.6)$ & $0.359^{\mathrm{a}}$ \\
\hline CAR (median min-max) & $1.10(0.23-4.6)$ & $2.23(0.3-14.8)$ & $0.132^{\mathrm{a}}$ \\
\hline
\end{tabular}

Correlation analysis showed that there was a significant and moderate positive correlation between CAR, ESR and DAS 28-ESR $(\mathrm{p}=0.002, \mathrm{rs}=0.426 ; \mathrm{p}<0.001, \mathrm{rs}=0.536$, respectively). Furthermore, there was a significant and strong positive correlation between CAR and CRP $(\mathrm{p}<0.001, \mathrm{rs}=0.994)$ (Table 4).

Table 4. C-reactive protein/albumin ratio (CAR) and its correlation with other clinical parameters

\begin{tabular}{lcc}
\hline Parameters & & CAR \\
\cline { 2 - 3 } & p value & rs \\
DAS 28- ESR & $\mathbf{0 . 0 0 2}$ & 0.426 \\
HAQ score & 0.301 & 0.149 \\
& $\mathbf{0 . 0 0 1}$ & 0.536 \\
& $\mathbf{0 . 0 0 1}$ & 0.994 \\
ESR (mm/h) & 0.757 & 0.045 \\
CRP (mg/dl & 0.766 & 0.043 \\
RF positive & & -0.041 \\
Anti-CCP positive & 0.779 & -0.04 \\
\hline
\end{tabular}




\begin{tabular}{lcc}
\hline SF -36 subscale & 0.428 & -0.115 \\
Physical Function & 0.607 & 0.074 \\
Physical Role Limitation & 0.564 & 0.084 \\
Emotional Role Limitation & 0.896 & 0.019 \\
Energy & 0.689 & -0.058 \\
Emotional Well-being & 0.909 & 0.017 \\
Social Functions & 0.893 & 0.019 \\
Pain & & \\
General Health & & \\
\hline
\end{tabular}

rs Spearman correlation coefficient, CAR; $C$ - reactive protein to albumin ratio, DAS28-ESR Disease activity score 28- Erythrocyte sedimentation rate, HAQ Health Assessment Questionnaire,

ESRErythrocyte sedimentation rate, RF Rheumatoid factor, Anti-CCP anti-citrullinated peptide, SF-36

Short-form 36

\section{Discussion}

The main finding of this study was the higher level of the CAR in the patients with highmoderate disease activity. There was a moderate positive correlation between ESR, CRP, and DAS 28-ESR scores. These results might support the role of CAR in inflammatory conditions such as RA. Some of the studies in the literature suggested that CAR value was superior to CRP in predicting mortality alone $(17,18)$. A study done by Yang et al.(8) showed that the positive correlation between CAR and CRP, ESR, and DAS 28 scores is similar to our findings. Therefore, CAR might be use in terms of disease activity in the patients with RA. Another study, comparing 32 Takayasu arteritis patients and 32 healthy controls, revealed that CAR was significantly correlated with disease activity, CRP, and ESR levels (19). Unlike the results of our study, Sunar et al (20) found a weak correlation between the CAR and DAS 28ESR in the RA patients. They stated that the CAR might be an additional marker in disease activity, among other markers. On the other hand, several previous studies have shown that CAR was increased in cancer and cardiovascular diseases, which may suggest that there is a relationship between inflammation and CAR $(21,22)$. Some studies suggested that CAR was a long term biomarker and it would give more precise results in mortality compared to CRP alone $(17,18)$.

The CRP divided into albumin levels is known as CAR. Albumin is not only related to nutritional status but also related to inflammation. In systemic inflammation, albumin levels decrease, and acute phase reactants increase. Therefore, there is an association between hypoalbuminemia and CRP levels (23). In our study, we did not have any patients with hypoalbuminemia. However, there was no difference in terms of albumin levels between groups, in intragroup comparison showed that patients with moderate-high disease activity had decreased albumin levels. Although many studies showed the relationship between CAR and other inflammatory conditions, few studies in the literature report its relationship with autoimmune diseases $(8,9,20)$. To the best of our knowledge, this is the second crosssectional study investigating the relationship between CAR and disease activity and quality of life in RA patients. We found that CAR was significantly higher in the high disease activity group than patients in remission and moderate to strongly associated with ESR, CRP, and DAS28-ESR scores. This result may be used as a positive indicator for the literature in terms of disease activity assessment in RA. However, we did not observe any correlation between CAR and quality of life and HAQ scores which may be related to the most patients have low disease activity in our study. Similar to our study, a recent study did not find any relationship between CAR and quality of life (20).

In our study, there were no differences in CAR levels, DAS 28-ESR, SF-36, and HAQ scores between conventional and biological DMARD groups regarding the drug treatment options. This may be arised from the 
suppressive effect of the given treatments on inflammation. Similar to our results, a recent study revealed no relationship in CAR and DAS28-ESR levels between biological and conventional DMARD therapy (20). Another study investigating the predictive factors for drug treatment in RA also reported that, among other factors, CRP was the most associated marker with the clinical outcomes of RA (24).

The DAS-28 scale is the most commonly used scale to determine disease activity for RA in clinics. However, applying this scale is timeconsuming in busy clinics. Since the CAR is an easily calculated laboratory data, it may be beneficial in time-saving in the evaluation of disease activity.

Serum RF and anti-CCP values are known as essential indicators in disease activity and

\section{REFERENCES}

1. Goldring SR. Periarticular bone changes in rheumatoid arthritis: pathophysiological implications and clinical utility. Ann Rheum Dis.2009;68:297-9.

2. Fardellone P, Séjourné A, Paccou J, Goëb V. Bone remodelling markers in rheumatoid arthritis. Mediators Inflamm. 2014;2014:484280.

3. Goekoop-Ruiterman YP, de Vries-Bouwstra JK, Allaart CF, van Zeben D, Kerstens PJ, Hazes JM, et al. Clinical and radiographic outcomes of four different treatment strategies in patients with early rheumatoid arthritis (the BeSt study): a randomized, controlled trial. Arthritis Rheum.2005;52:3381-90.

4. Buzatu C, Moots RJ. Measuring disease activity and response to treatment in rheumatoid arthritis. Expert Rev Clin Immunol. 2019;15:135-45.

5. Aletaha D, Funovits J, Breedveld FC, Sharp J, Segurado O, Smolen JS. Rheumatoid arthritis joint progression in sustained remission is determined by disease activity levels preceding the period of radiographic assessment. Arthritis Rheum.2009;60:1242-9.

6. Nakken B, Papp G, Bosnes V, Zeher M, Nagy G, Szodoray P. Biomarkers for rheumatoid arthritis: From molecular processes to diagnostic applications-current concepts and future perspectives. Immunology Lett. 2017;189:13-8. progression (25). However, we did not detect a correlation between CAR and RF and antiCCP values in this study which may be related to the small sample size of our study.

This study had some limitations. First, our study was a cross-sectional study, and there were no control patients. The second limitation is the small sample size which may weaken the generalizing of the results. More precise results can be obtained with further randomized-controlled clinical studies in which the sample size is increased.

\section{Conclusion}

This study provided evidence of the relationship between CAR and disease activity. Our results suggest that CAR may be used in clinics to determine inflammation and disease activity as an inexpensive and easily applicable biomarker.

7. Colglazier CL, Sutej PG. Laboratory testing in the rheumatic diseases: a practical review. South Med J.2005;98:185-91.

8. Yang WM, Zhang WH, Ying HQ, Xu YM, Zhang J, Min QH, et al. Two new inflammatory markers associated with disease activity score- 28 in patients with rheumatoid arthritis: Albumin to fibrinogen ratio and C-reactive protein to albumin ratio. Int Immunopharmacol. 2018;62:293-8.

9. He Y, Tang J, Wu B, Yang B, Ou Q, Lin J. Correlation between albumin to fibrinogen ratio, C-reactive protein to albumin ratio and Th17 cells in patients with rheumatoid arthritis. Clin Chim Acta. .2020;500:149-54.

10. Aletaha D, Neogi T, Silman AJ, Funovits J, Felson DT, Bingham CO, et al. 2010 Rheumatoid arthritis classification criteria: an American College of Rheumatology/European League Against Rheumatism collaborative initiative. Arthritis Rheum. 2010;62:2569-81.

11. Fransen J, van Riel PL. The Disease Activity Score and the EULAR response criteria. Rheum Dis Clin North Am.2009;35:745-57.

12. Aletaha D, Ward MM, Machold KP, Nell VP, Stamm T, Smolen JS. Remission and active disease in rheumatoid arthritis: defining criteria for disease activity states. Arthritis Rheum. 2005;52:2625-36.

13. Küçükdeveci AA, Sahin $H$, Ataman S, Griffiths B, Tennant A. Issues in crosscultural validity: example from the adaptation, reliability, and validity testing of 
a Turkish version of the Stanford Health Assessment Questionnaire. Arthritis Rheum. 2004;51:14-9.

14. Bruce B, Fries JF. The Stanford Health Assessment Questionnaire: dimensions and practical applications. Health Qual Life Outcomes. 2003;1:20.

15. Ware JE, Jr., Kosinski M, Bayliss MS, McHorney CA, Rogers WH, Raczek A. Comparison of methods for the scoring and statistical analysis of SF-36 health profile and summary measures: summary of results from the Medical Outcomes Study. Med Care.1995;33(4 Suppl):As264-79.

16. Kaya BB, İçağasığlu. Reliability and validity of the Turkish version of short form 36 (SF-36) in patients with rheumatoid arthritis. J Surg Med. 2018;2:11-16.

17. Oh TK, Song IA, Lee JH. Clinical usefulness of C-reactive protein to albumin ratio in predicting 30-day mortality in critically ill patients: A retrospective analysis. Sci Rep. 2018;8:14977.

18. Ranzani OT, Zampieri FG, Forte DN, Azevedo LC, Park M. C-reactive protein/albumin ratio predicts 90-day mortality of septic patients. PloS one. 2013;8:e59321.

19. Seringec Akkececi N, Yildirim Cetin G, Gogebakan H, Acipayam C. The C-Reactive Protein/Albumin Ratio and Complete Blood Count Parameters as Indicators of Disease Activity in Patients with Takayasu Arteritis. Med Sci Monit. 2019;25:1401-9.

20. Sunar İ, Ataman Ş. Serum C-Reactive Protein/Albumin Ratio in Rheumatoid Arthritis and its Relationship With Disease Activity, Physical Function, and Quality of Life. Arch Rheumatol. 2020;35:247-53.

21. Zou Y-X, Qiao J, Zhu H-Y, Lu R-N, Xia Y, Cao L, et al. Albumin-to-fibrinogen ratio as an independent prognostic parameter in untreated chronic lymphocytic leukemia: a retrospective study of 191 cases. Cancer Res Treat. 2019;51:664.

22. Shimizu T, Ishizuka M, Suzuki T, Tanaka G, Shiraki T, Sakuraoka Y, et al. The Value of the C-Reactive Protein-to-Albumin Ratio is Useful for Predicting Survival of Patients with Child-Pugh Class A Undergoing Liver Resection for Hepatocellular Carcinoma. World J Surg. 2018;42:2218-26.

23. Barber MD, Ross JA, Fearon KC. Changes in nutritional, functional, and inflammatory markers in advanced pancreatic cancer. Nutr Cancer. 1999;35:106-10.

24. Hayashi S, Matsubara T, Fukuda K, Funahashi K, Hashimoto M, Maeda T, et al. Predictive factors for effective selection of Interleukin-6 inhibitor and tumor necrosis factor inhibitor in the treatment of rheumatoid arthritis. Sci Rep. 2020;10:16645.

25. Choe JY, Bae J, Lee H, Bae SC, Kim SK. Relation of rheumatoid factor and anti-cyclic citrullinated peptide antibody with disease activity in rheumatoid arthritis: cross- sectional study. Rheumatol Int. 2013;33:2373-9. 